\title{
Geochemistry of Middle Holocene Sediments from South Yellow Sea: Implications to Provenance and Climate Change
}

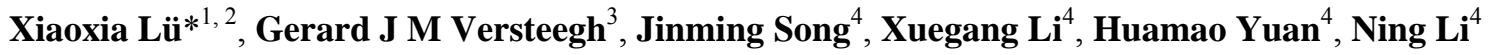 \\ 1. Faculty of Resources, China University of Geosciences, Wuhan 430074, China \\ 2. State Key Laboratory of Biogeology and Environmental Geology, China University of Geosciences, Wuhan 430074, China \\ 3. Heisenberg group on Marine Kerogen, Center for Marine Environmental Sciences (MARUM), Bremen University, \\ Bremen D-28359, Germany \\ 4. Institute of Oceanology, Chinese Academy of Sciences, Qingdao 266072, China
}

\begin{abstract}
From a large number of case studies on terrestrial deposits we know that Late Holocene climate fluctuations have an important impact on the terrestrial environments. However, it is hitherto not clear how the marine sediments can be used to shed light on the environment and climate change of the catchment. To provide such insight, we used the major element, trace element and rare earth element (REE) compositions in the southern Yellow Sea (SYS) sediments to reconstruct the changes in weathering and erosion of their source regions. The sediments originate predominantly from the upper crust of East China and are transported into the basin especially by the Yellow River (Huanghe) and to a lesser extent by the Yangtze River (Changjiang). The chemical index of alteration (CIA; 53.7-59.7) suggests low chemical weathering of the source rocks since the Middle Holocene. This is consistent with the relatively cool and arid climate in North China after the Holocene Megathermal. Comparison of element ratios, including $\mathrm{Al} / \mathrm{Ca}, \mathrm{K} / \mathrm{Ca}, \mathrm{Al} / \mathrm{Na}, \mathrm{K} / \mathrm{Na}, \mathrm{Rb} / \mathrm{Sr}, \mathrm{Li} / \mathrm{Ba}$ and the $\mathrm{CIA}$ shows that we can use the latter as a robust proxy for climate change. The CIA-based mean annual precipitation and mean annual temperature show a series of climate fluctuations in the catchment. A relatively warm and humid Period I (5.3-2.9 cal. ka BP), a relatively cool and dry Period II (2.9-0.9 cal. ka BP) and an increasingly cool and dry Period III (0.9-0.3 cal. ka BP). These periods can be linked to climate intervals recognized elsewhere.
\end{abstract}

KEY WORDS: geochemical composition, elemental ratio, climate change, provenance, south Yellow Sea sediment.

\section{O INTRODUCTION}

The climate in central and northern China is mainly controlled by the East Asian Summer Monsoon and the Siberian-Mongolia High Winter Monsoon (Wang and Lin, 2002; Chen et al., 1991). As a result, cold and dry northwestern winds from the subarctic prevail in winter. In summer, the region is under the control of the warm humid southeastern winds of tropical/subtropical origin, leading to abundant precipitation. Although over the entire Holocene, climate was regarded as stable (Schulz et al., 1998; Grootes and Stuiver, 1997; Dansgarrd et al., 1993), at decadal or centennial scale, significant climate change occurs, such as the Holocene Megathermal and the Little Ice Age (e.g., Kong et al., 2014; Jin and Liu, 2002; Dahl and Nesje, 1996; Porter and An, 1995; Harrison and Digerfeldt, 1993; Shi et al., 1992). This is also evident for China from the analysis of e.g., loess, peat and lake sediments

\footnotetext{
*Corresponding author: luxiaox@163.com

(C) China University of Geosciences and Springer-Verlag Berlin Heidelberg 2015
}

Manuscript received July 24, 2014.

Manuscript accepted November 7, 2014. (e.g., Morrill et al., 2006; Wang et al., 2004; Shi et al., 1999; Gasse et al., 1991). However, it is hitherto not clear how these changes influenced weathering and erosion at larger spatial scales such as entire drainage basin.

The southern Yellow Sea (SYS) is located between China mainland and Korea Peninsula. The sediments in SYS mainly derive from the Yellow River, Yangtze River and Luanhe River (Yang et al., 2003; Park et al., 2000; Milliman et al., 1985a, b ). Analyses of the SYS sediments used to focus on provenance (Youn and Kim, 2011; Yang and Youn, 2007; Qin et al., 1989; Ren and Shi, 1986; Chough and Kim, 1981). However, recently, environment and climate change have been inferred through analyzing the sediment properties (e.g., grain size, geochemical compositions, micropaleontology, magnetics) of the mud sediments in the middle and eastern Yellow Sea (Liu et al., 2009; Xiang et al., 2008; Ge et al., 2005; Cheng et al., 2001; Kim and Kennett, 1998). Sediments of the western shelf of the southern Yellow Sea are mainly supplied by the Yellow and Yangtze rivers (Alexander et al., 1991; Milliman et al., 1985a, b), so that they contain information on environment and climate changes in the catchments of these rivers, i.e., central and northern China.

Sediments of coastal shelf systems are mainly composed of river-derived clastics. The composition of these clastics is a

Lü, X. X., Versteegh, G. J. M., Song, J. M., et al., 2015. Geochemistry of Middle Holocene Sediments from South Yellow Sea: Implications to Provenance and Climate Change. Journal of Earth Science, online. doi:10.1007/s12583-015-0577-0. http://en.earth-science.net 
function of the source rock characteristics, chemical weathering, sorting processes during transportation, sedimentation and post-depositional diagenetic alterations (Nesbitt and Young, 1996; McLennan, 1989). Several of these factors are directly or indirectly influenced by climate such as the chemical weathering intensity (Goldberg and Humayun, 2010; Nesbitt and Young, 1996), transportation, sedimentation and post-depositional diagenesis (Gao et al., 2000; Alexander et al., 1991; DeMaster et al., 1985). As such, chemical records of marine sediments can be used to reconstruct not only provenance but also climate change in the source regions (Youn and Kim, 2011; Wang et al., 2007; Yang et al., 2004b), provided the signals from the different sediment sources can be sufficiently separated and no significant chemical weathering occurs during transport and after deposition.

Elemental ratios, such as $\mathrm{Rb} / \mathrm{Sr}, \mathrm{Li} / \mathrm{Ba}, \mathrm{K} / \mathrm{Na}$ and $\mathrm{K} / \mathrm{Ca}$, are used to evaluate the intensity of chemical weathering in sediments (Chen et al., 1999; Nesbitt and Young, 1982). In general, due to weathering of parent rocks, the content of $\mathrm{Na}$ and $\mathrm{Ca}$ in the resulting sediments is lower for the selective removal of these elements, while $\mathrm{K}$ and $\mathrm{Mg}$ increase for their easy adsorption by clay. As a result, the inactive elements, such as $\mathrm{Al}$ and $\mathrm{Ti}$, are enriched in the residue (Das and Krishnaswami, 2007; Nesbitt and Young, 1996; Nesbitt et al., 1980). Therefore, the elemental ratios such as $\mathrm{Al} / \mathrm{Na}, \mathrm{Al} / \mathrm{Ca}, \mathrm{K} / \mathrm{Na}$ and $\mathrm{K} / \mathrm{Ca}$ can be used to evaluate the intensity of chemical weathering with higher ratios reflecting stronger weathering (Yang et al., 2004a).

$\mathrm{Rb}$ and $\mathrm{Sr}$ are typical dispersed elements, existing in rock minerals in isomorphism form. Rb mainly occurs in K-bearing minerals, such as biotite, muscovite, and potash feldspar, whereas $\mathrm{Sr}$ occurs in Ca-bearing minerals. Since the K-bearing minerals are more stable than the carbonates, during weathering, $\mathrm{Rb}$ is kept in the source area whereas $\mathrm{Sr}$ is removed resulting in a change of the $\mathrm{Rb} / \mathrm{Sr}$ ratio (Goldstein, 1988). This mechanism explains why in active and relict weathering profiles and loess-paleosol sequences the $\mathrm{Rb} / \mathrm{Sr}$ ratio in weathered debris increases with weathering intensity (Chen et al., 1999; Dasch, 1969). Furthermore, in detrital particles Sr cannot exchange with $\mathrm{Sr}$ in water to balance its concentration during transportation and deposition (Ingram and Sloan, 1992). The half life of ${ }^{87} \mathrm{Sr}$ is $4.88 \times 10^{10}$ years so that decay of this isotope has no significant influence on the $\mathrm{Sr}$ content on the time scale of millennia. Therefore, the variation of $\mathrm{Rb}$ and $\mathrm{Sr}$ in Holocene sediment primarily reflects weathering.

Usually, during the weathering processes, $\mathrm{Li}$ is kept in the source area, whereas $\mathrm{Ba}$ is easily dissolved and transported so that the elemental ratio of $\mathrm{Li} / \mathrm{Ba}$ is also used as an index for chemical weathering, whereby a higher ratio suggests a stronger chemical weathering in the source area (Jia et al., 2005).

The chemical index of alteration (CIA) is used to quantify the chemical weathering of the rocks, expressing the selective removal of mobile elements such as $\mathrm{Na}, \mathrm{Ca}$, and $\mathrm{K}$ (Xiong et al., 2010; Roy et al., 2008; Nesbitt and Young, 1982). The CIA values of fresh rocks and minerals are $<50$ (Nesbitt and Young, 1982). CIA values between 50 and 60 indicate low chemical weathering, reflecting a relatively cool and arid climate. Values between 60 and 80 suggest moderate chemical weathering, whereas values $>80$ are characteristic for intensive chemical weathering in tropical and humid environments (Fedo et al., 1995; Nesbitt and Young, 1982). In marine sediments, the CIA may also be used as an index for environmental and climatic change since it is not influenced by water dynamics and in sediment cores changes in the CIA can be mainly attributed to changes in the weathering of the source region(s) (Cole et al., 2009; Hemming, 2007; Colin et al., 2006; Eisenhauer et al., 1999; McLennan et al., 1990).

To shed more light on the correlation between climate and environment, we analyzed sediments from the South Yellow Sea to identify sediment sources, to evaluate the chemical weathering intensities through time and to demonstrate climate changes since the Middle Holocene for central and northern China. The use of the elemental composition and elemental ratios for reconstructing the environmental changes in river catchment areas is a relatively new development.

\section{SAMPLING AND METHODS}

\subsection{Sampling}

Gravity-core D7 $\left(33^{\circ} 34.7^{\prime} \mathrm{N}, 122^{\circ} 32.0^{\prime}\right.$ E) was obtained from the western shelf of the SYS in October 2006 (Fig. 1). The total core length is $81 \mathrm{~cm}$. The sediment was sliced at $2 \mathrm{~cm}$ intervals and stored in the refrigerator till analysis.

\subsection{Geochemical Composition}

Samples were dried in an oven at $60{ }^{\circ} \mathrm{C}$ for $24 \mathrm{~h}$, homogenized and subsequently finely ground in an agate mortar. For each sample, $40 \mathrm{mg}$ of powdered sediment were put into a Teflon vessel and $0.6 \mathrm{~mL} \mathrm{HNO}_{3}$ and $2 \mathrm{~mL} \mathrm{HF}$ were added. Hereafter, the vessels were sealed, and heated at $150{ }^{\circ} \mathrm{C}$ for $24 \mathrm{~h}$. After cooling, the vessels were opened to add $0.5 \mathrm{~mL} \mathrm{HClO}_{4}$, and the samples were heated to almost dryness (no obvious liquid). After that, $1 \mathrm{~mL} \mathrm{HNO}_{3}$ and $1 \mathrm{~mL} \mathrm{H}_{2} \mathrm{O}$ were added the vessels were sealed again and heated at $120^{\circ} \mathrm{C}$ for $12 \mathrm{~h}$. The final solution was transferred to a polyethylene bottle and diluted to $40 \mathrm{~mL}$. The major elements were determined by ICP-AES (IRIS Intrepid II), and the trace and the rare Earth elements (REE) were determined by ICP-MS (DRC II). Precision and accuracy were assessed through replicate analysis of national standards of marine sediment (GBW07315 and GBW07316) and blanks. Analytical uncertainties for major and trace (including REE) elements are generally less than $3.5 \%$ and $8.2 \%$, respectively.

\subsection{Chronology}

The age model of the core is based on the activity profiles of the ${ }^{210} \mathrm{~Pb}$ and ${ }^{137} \mathrm{Cs}$ as well as $\mathrm{AMS}^{14} \mathrm{C}$ of planktonic foraminifers in the two upper layers and of bulk organic matter in the bottom layer, (Lü et al., 2014). According to this model the core bottom has an age of $5.25 \mathrm{cal}$. ka BP whereas the core top has an age of 0.31 cal. ka BP. The age accuracy of the individual sample is about \pm 56 years.

\subsection{Statistic and Proxy Calculation}

Principal component analysis (PCA) of all the elements was performed to distinguish the factors controlling the distribution of elements in core D7 sediments.

The CIA was calculated using the Eq. 1 proposed by Nesbitt and Young (1982). 


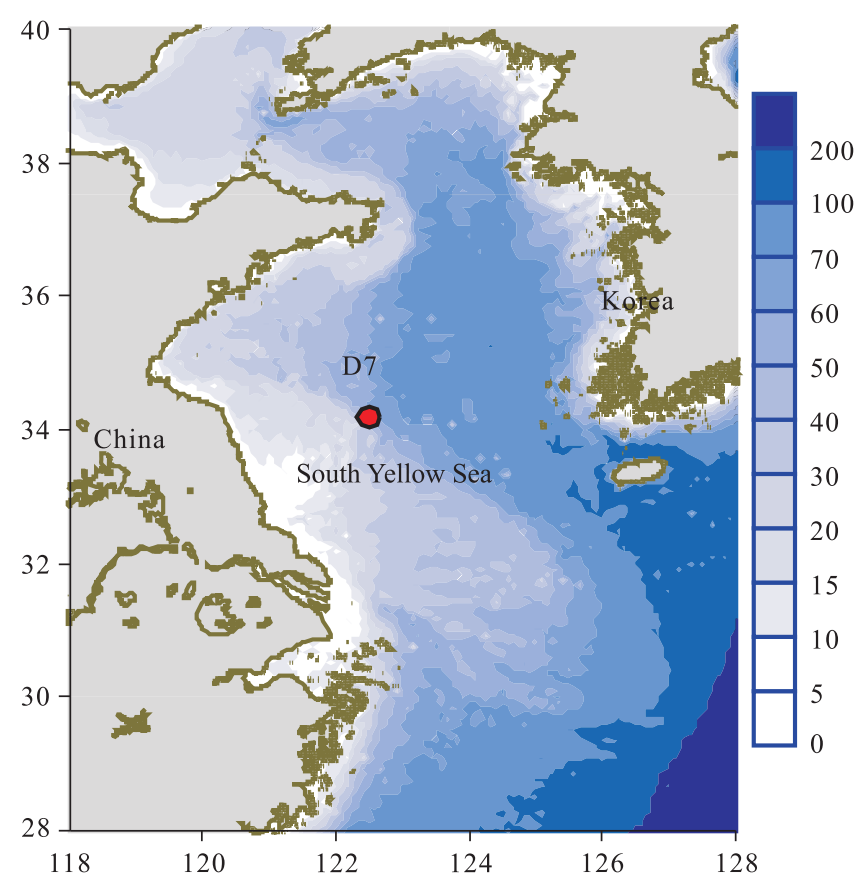

Figure. 1 Sampling site of the South Yellow Sea.

$$
\mathrm{CIA}=\mathrm{Al}_{2} \mathrm{O}_{3} /\left(\mathrm{Al}_{2} \mathrm{O}_{3}+\mathrm{CaO} *+\mathrm{Na}_{2} \mathrm{O}+\mathrm{K}_{2} \mathrm{O}\right) \times 100
$$

Here, $\mathrm{CaO}^{*}$ refers to the concentration of $\mathrm{CaO}$ in silicate minerals. $\mathrm{CaO}^{*}$ was measured according to McLennan (1993), which assumes that the molar $\mathrm{CaO} / \mathrm{Na}_{2} \mathrm{O}$ ratio of silicates is not higher than one. If the molar $\mathrm{CaO}$ content (corrected for apatite) was less than that of $\mathrm{Na}_{2} \mathrm{O}$, it was taken as $\mathrm{CaO}^{*}$. Otherwise, the $\mathrm{CaO}$ content of silicates was assumed to be equivalent to the molar $\mathrm{Na}_{2} \mathrm{O}$ content (McLennan, 1993).

The chemical weathering intensity in the $\mathrm{B}$ horizon of soil (have ages of $10^{3}-10^{5} \mathrm{yrs}$ ) can be used to estimate the mean annual precipitation (MAP) and mean annual temperature (MAT) using geochemical climofunctions derived from the modern North American soils (Eqs. (2) and (4)) (Retallack, 2009; Sheldon et al., 2002). The ages of humin in the three layers of Core D7 (4-6, 52-54 and 80-81 cm) are $14058 \pm$ $111,13501 \pm 54$ and $13163 \pm 50$ cal. ka BP (Lü et al., 2014). These represent the ages of the paleosols because the humin is the oldest fraction of soil (Yin et al., 2007). The result suggests that the source soil of Core D7 sediment is from the B horizon. Therefore, the chemical weathering intensity can be used to reconstruct the MAP and MAT in the catchment.

$$
\begin{aligned}
& \mathrm{MAP}=221 \mathrm{e}^{0.019} 7 \text { (CIA-K) } \quad R^{2}=0.72 \\
& \text { CIA-K }=100 \times\left(\mathrm{mAl}_{2} \mathrm{O}_{3} /\left(\mathrm{mAl}_{2} \mathrm{O}_{3}+\mathrm{mCao}^{2} \mathrm{mNa}_{2} \mathrm{O}\right)\right) \\
& \text { (Maynard, 1992) } \\
& \text { MAT }=-18.5 \times\left(\mathrm{Na}_{2} \mathrm{O}+\mathrm{K}_{2} \mathrm{O}\right) / \mathrm{Al}_{2} \mathrm{O}_{3}+17.3 \quad R^{2}=0.37
\end{aligned}
$$

Here the $\left(\mathrm{Na}_{2} \mathrm{O}+\mathrm{K}_{2} \mathrm{O}\right) / \mathrm{Al}_{2} \mathrm{O}_{3}$ refers to the molecular ratio.

\section{RESULTS}

\subsection{Major Elements}

Most of the major elements and compounds $\left(\mathrm{Al}_{2} \mathrm{O}_{3}\right.$,
$\mathrm{Fe}_{2} \mathrm{O}_{3}, \mathrm{~K}_{2} \mathrm{O}, \mathrm{MgO}, \mathrm{TiO}_{2}$ and $\mathrm{MnO}$ ) show similar distributions for the investigated interval (Fig. 2), which we divided into three periods: I, 5.25-3.05 cal. ka BP; II, 3.05-1.1 cal. ka BP and III, 1.1-0.31 cal. ka BP. The concentrations of major elements increase abruptly at first and then decrease slowly during Period I. In Period II the overall increase is superimposed by short-term fluctuations. Finally, in Period III, the concentrations decrease again. The distribution of $\mathrm{CaO}, \mathrm{Na}_{2} \mathrm{O}$ and $\mathrm{P}_{2} \mathrm{O}_{5}$ is different from that of $\mathrm{Al}_{2} \mathrm{O}_{3}$. The content of $\mathrm{CaO}$ is relatively stable before 0.9 cal. ka $\mathrm{BP}$, and after that increases abruptly. The $\mathrm{Na}_{2} \mathrm{O}$ content increases slowly during the investigated period. The $\mathrm{P}_{2} \mathrm{O}_{5}$ content also is relatively stable before $1.3 \mathrm{cal}$. ka $\mathrm{BP}$, increases from 1.3 to $0.6 \mathrm{cal}$. ka BP, and decreases hereafter.

\subsection{Trace Elements}

On the basis of their temporal distributions the trace elements have been divided into Group $\mathrm{A}$, including $\mathrm{Li}, \mathrm{Rb}$ and Th; Group B, including Ba and $\mathrm{U}$; and Group $\mathrm{C}$ including $\mathrm{Sr}$ only (Fig. 3). In Group A, the element distributions can be divided into the same three periods as defined above for most of the major elements. In Group B, the element distribution differs from that of Group A in which they have the highest content at $1.1 \mathrm{cal}$. ka BP. The distribution of $\mathrm{Sr}$ (Group C) is significantly different from those of the other elements. The concentrations of $\mathrm{Sr}$ show little variation throughout the core. They are highest in the core top.

\subsection{REEs}

For the composition and chronological distributions of total rare earth elements (¿REE) (Table 1 and Fig. 4), light rare earth elements (LREE) were the principal component and accounted for about $90.2 \%,(89.8 \%$ to $90.5 \%)$. The chronological distribution of REE also follows the three periods defined above. The heavy rare earth elements (HREE) differ from the LREE in showing a continuous decrease in the upper layer but still follow the three periods in their overall pattern. The LREE are dominated by the distributions of $\mathrm{Ce}$, $\mathrm{La}$ and $\mathrm{Nd}$, while the HREE are dominated by Gd (Fig. $4)$.

\subsection{Factor Analysis}

Three factors could be extracted based on eigenvalues $>1$ (Table 2). Some elements show high scores for each factor (Table 3), which suggest that each factor has marked significance and the different element group is affected by different environment parameter. The variance contribution of factor 1 is $61.8 \%$ in primary factor extraction. The representative elements for factor 1 are $\mathrm{Li}, \mathrm{Rb}, \mathrm{Ba}, \mathrm{Al}_{2} \mathrm{O}_{3}, \mathrm{Fe}_{2} \mathrm{O}_{3}$, $\mathrm{K}_{2} \mathrm{O}, \mathrm{MgO}, \mathrm{MnO}, \mathrm{TiO}_{2}$ and $\mathrm{REE}$. The variance contribution of factor 2 is $16.0 \%$, which becomes $27.4 \%$ after rotating. The representative elements for factor 2 are $\mathrm{CaO}, \mathrm{Sr}$, $\mathrm{Na}_{2} \mathrm{O}$ and $\mathrm{P}_{2} \mathrm{O}_{5}$. The variance contribution of factor 3 is $8.1 \%$, which becomes $19.4 \%$ after rotating. The representative element is $\mathrm{P}_{2} \mathrm{O}_{5}$. 


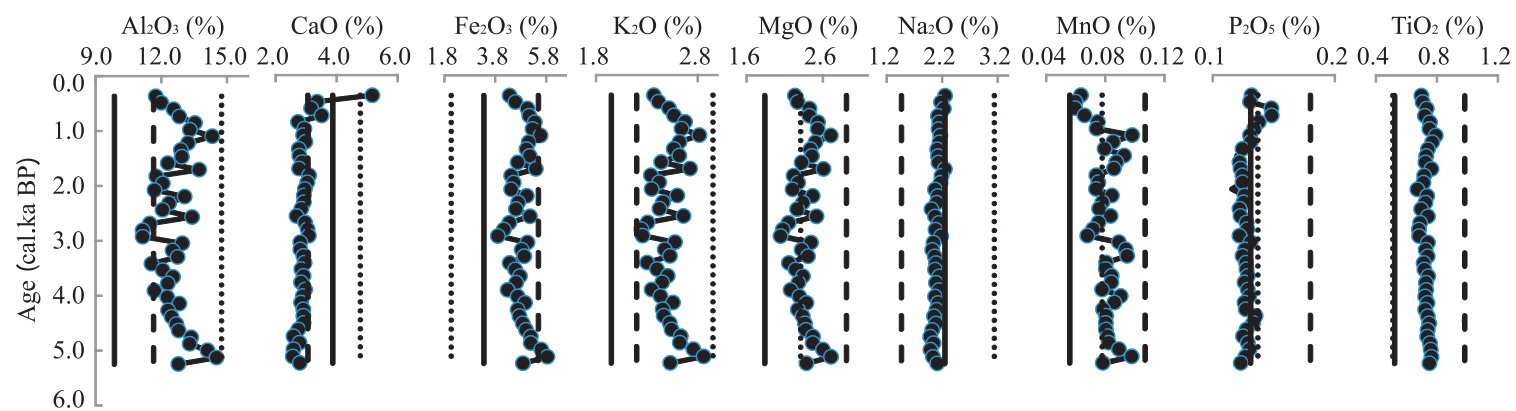

Figure 2. Chronological distribution of major elements in Core D7 in South Yellow Sea. Discontinuous line representing the average content in Yangtze River sediment (CJS), black line representing the average content in Yellow River sediment (HHS) (Yang and Li, 1999b), dot line representing the average content in upper continental crust of East China (UCCEC) (Yan et al., 1997).

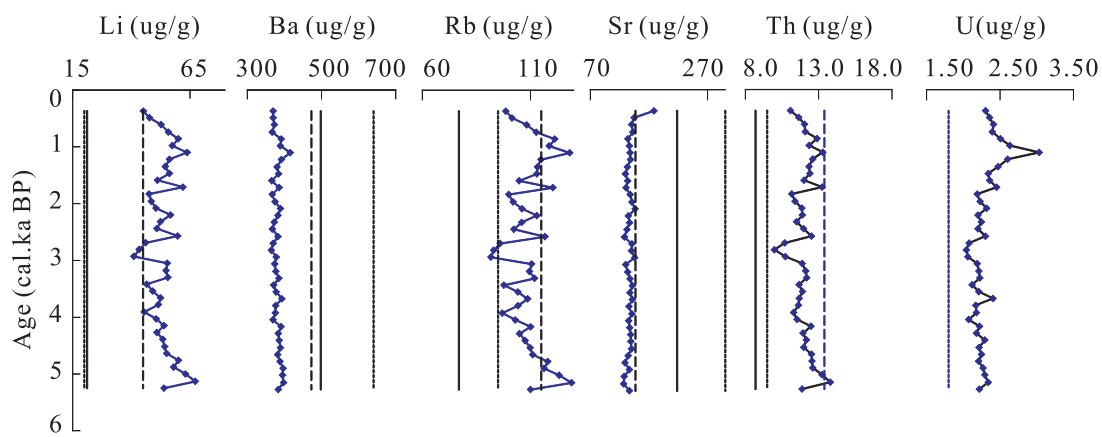

Figure 3. Chronological distributions of trace elements in Core D7 sediment in South Yellow Sea. Discontinuous line representing the average content in Young River (CJS), black line representing the average content in Yellow River sediment (HHS) (Yang et al., 2003), dot line representing the average content in upper continental crust of east China (UCCEC) (Yan et al., 1997).

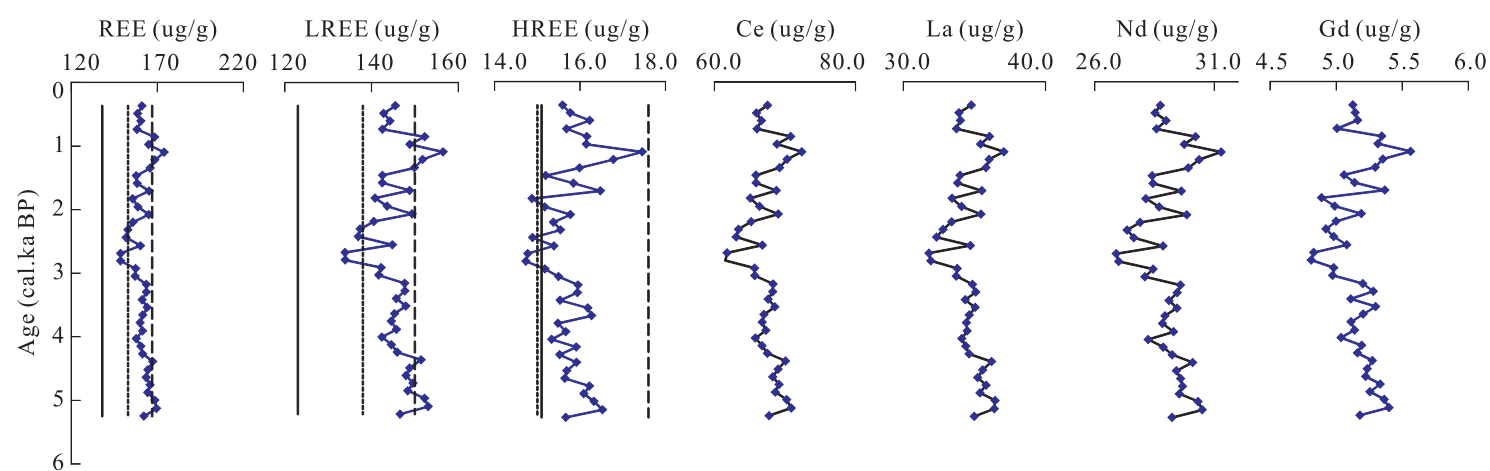

Figure 4. Chronological distributions of REE in Core D7 sediment in South Yellow Sea. Dash line representing the average content in CJS, black line representing the average content in HHS (Yang and Li, 1999a), dot line representing the average content in UCCEC (Yan et al., 1997).

\subsection{MAT and MAP}

The reconstructed mean annual temperature (MAT) ranges from $6.8{ }^{\circ} \mathrm{C}$ to $9.1{ }^{\circ} \mathrm{C}$, with an average of $8.2{ }^{\circ} \mathrm{C}$ in the research epoch. The reconstructed mean annual precipitation (MAP) ranges from 704 to $850 \mathrm{~mm}$, with an average of $785 \mathrm{~mm}$ (Fig. 7).

\section{DISCUSSION}

\subsection{Factor Analysis}

Factor 1 with $\mathrm{Li}, \mathrm{Rb}, \mathrm{Ba}, \mathrm{Al}_{2} \mathrm{O}_{3}, \mathrm{Fe}_{2} \mathrm{O}_{3}, \mathrm{~K}_{2} \mathrm{O}, \mathrm{MgO}, \mathrm{MnO}$, $\mathrm{TiO}_{2}$ and REE, we interpret as usual, representing the terrestrial input of rock provenance for their relatively stable characteris- tics (Nesbitt and Markovics, 1997; Nesbitt and Young, 1982). Factor 2, with $\mathrm{CaO}, \mathrm{Sr}, \mathrm{Na}_{2} \mathrm{O}$ and $\mathrm{P}_{2} \mathrm{O}_{5}$, is related to marine biogenic products and depositional conditions besides source rock characteristics (Stoll and Schrag, 2000, 1998). The score of factor 3 is relatively low, which suggests that the distribution of $\mathrm{P}$ is affected by many factors, such as sediment source, productivity and biogeochemical processes.

\subsection{Sediment Provenance}

Sediments from the western coast of the South Yellow Sea have been regarded mainly as coming from the modern and old 
Table 1 Composition of REE in core D7 sediments in South Yellow Sea

\begin{tabular}{|c|c|c|c|c|c|c|c|c|c|c|c|c|c|c|c|c|c|c|}
\hline Depth & cal. ka BP & $\mathrm{La}$ & $\mathrm{Ce}$ & $\operatorname{Pr}$ & $\mathrm{Nd}$ & $\mathrm{Sm}$ & $\mathrm{Eu}$ & $\mathrm{Gd}$ & $\mathrm{Tb}$ & Dy & Но & $\mathrm{Er}$ & $\mathrm{Tm}$ & $\mathrm{Yb}$ & $\mathrm{Lu}$ & LREE & HREE & $\sum \mathrm{REE}$ \\
\hline$(\mathrm{cm})$ & $(1950 \mathrm{AD})$ & & & & & & & & & $(\mu \mathrm{g} / \mathrm{g})$ & & & & & & & & \\
\hline 1 & 0.37 & 34.8 & 67.5 & 7.68 & 28.7 & 5.6 & 1.17 & 5.13 & 0.74 & 3.9 & 0.83 & 2.23 & 0.35 & 2.11 & 0.32 & 146 & 15.6 & 161 \\
\hline 3 & 0.49 & 33.9 & 66 & 7.64 & 28.5 & 5.59 & 1.17 & 5.14 & 0.74 & 3.92 & 0.84 & 2.28 & 0.35 & 2.16 & 0.33 & 143 & 15.8 & 159 \\
\hline 5 & 0.61 & 34 & 66.7 & 7.66 & 29 & 5.74 & 1.19 & 5.16 & 0.79 & 4.08 & 0.87 & 2.38 & 0.36 & 2.25 & 0.34 & 144 & 16.2 & 161 \\
\hline 7 & 0.74 & 33.7 & 66 & 7.55 & 28.6 & 5.45 & 1.18 & 5.01 & 0.76 & 3.96 & 0.83 & 2.27 & 0.36 & 2.18 & 0.32 & 143 & 15.7 & 158 \\
\hline 9 & 0.86 & 36.1 & 70.8 & 8.06 & 30.2 & 5.9 & 1.23 & 5.35 & 0.76 & 4.02 & 0.87 & 2.31 & 0.37 & 2.16 & 0.33 & 152 & 16.2 & 168 \\
\hline 11 & 0.98 & 35.4 & 68.9 & 7.82 & 29.7 & 5.77 & 1.21 & 5.32 & 0.75 & 3.99 & 0.86 & 2.31 & 0.36 & 2.23 & 0.34 & 149 & 16.2 & 165 \\
\hline 13 & 1.1 & 37.1 & 72.4 & 8.33 & 31.3 & 6.15 & 1.29 & 5.56 & 0.82 & 4.44 & 0.95 & 2.5 & 0.4 & 2.43 & 0.36 & 157 & 17.5 & 174 \\
\hline 15 & 1.22 & 36 & 70.3 & 8.01 & 30.4 & 5.87 & 1.21 & 5.35 & 0.78 & 4.23 & 0.91 & 2.47 & 0.38 & 2.3 & 0.35 & 152 & 16.8 & 169 \\
\hline 17 & 1.35 & 35.8 & 69.2 & 7.96 & 29.9 & 5.77 & 1.21 & 5.3 & 0.74 & 3.97 & 0.86 & 2.26 & 0.35 & 2.19 & 0.33 & 150 & 16 & 166 \\
\hline 19 & 1.47 & 34 & 65.9 & 7.56 & 28.4 & 5.54 & 1.16 & 5.06 & 0.7 & 3.77 & 0.8 & 2.15 & 0.34 & 2.07 & 0.31 & 143 & 15.2 & 158 \\
\hline 21 & 1.59 & 33.8 & 65.9 & 7.59 & 28.4 & 5.61 & 1.16 & 5.14 & 0.76 & 4.02 & 0.86 & 2.25 & 0.35 & 2.15 & 0.33 & 143 & 15.9 & 158 \\
\hline 23 & 1.71 & 35.5 & 68.8 & 7.86 & 29.6 & 5.83 & 1.21 & 5.37 & 0.76 & 4.12 & 0.88 & 2.38 & 0.37 & 2.26 & 0.34 & 149 & 16.5 & 165 \\
\hline 25 & 1.83 & 33.4 & 65.1 & 7.53 & 28.14 & 5.49 & 1.14 & 4.89 & 0.71 & 3.67 & 0.78 & 2.17 & 0.33 & 2.02 & 0.31 & 141 & 14.9 & 156 \\
\hline 27 & 1.96 & 34.1 & 66.4 & 7.68 & 28.7 & 5.6 & 1.16 & 4.99 & 0.72 & 3.74 & 0.8 & 2.21 & 0.34 & 2.06 & 0.32 & 144 & 15.2 & 159 \\
\hline 29 & 2.08 & 35.5 & 69.1 & 7.99 & 29.85 & 5.82 & 1.21 & 5.19 & 0.75 & 3.89 & 0.83 & 2.3 & 0.35 & 2.14 & 0.33 & 149 & 15.8 & 165 \\
\hline 31 & 2.2 & 33.4 & 65.2 & 7.44 & 27.9 & 5.49 & 1.15 & 5 & 0.74 & 3.89 & 0.82 & 2.19 & 0.35 & 2.07 & 0.32 & 141 & 15.4 & 156 \\
\hline 33 & 2.32 & 32.8 & 63.4 & 7.34 & 27.4 & 5.38 & 1.13 & 4.92 & 0.73 & 3.96 & 0.84 & 2.23 & 0.36 & 2.18 & 0.32 & 137 & 15.6 & 153 \\
\hline 35 & 2.44 & 32.3 & 63.1 & 7.26 & 27.6 & 5.54 & 1.1 & 4.98 & 0.7 & 3.69 & 0.78 & 2.11 & 0.33 & 2 & 0.3 & 137 & 14.9 & 152 \\
\hline 37 & 2.57 & 34.7 & 66.8 & 7.68 & 28.9 & 5.61 & 1.16 & 5.08 & 0.74 & 3.85 & 0.8 & 2.17 & 0.35 & 2.1 & 0.31 & 145 & 15.4 & 160 \\
\hline 39 & 2.69 & 31.8 & 61.8 & 7.08 & 26.9 & 5.23 & 1.11 & 4.83 & 0.7 & 3.67 & 0.79 & 2.1 & 0.33 & 2.05 & 0.3 & 134 & 14.8 & 149 \\
\hline 41 & 2.81 & 31.9 & 61.5 & 7.11 & 27 & 5.27 & 1.1 & 4.81 & 0.69 & 3.67 & 0.78 & 2.13 & 0.32 & 2.02 & 0.3 & 134 & 14.7 & 149 \\
\hline 43 & 2.93 & 33.8 & 65.7 & 7.61 & 28.4 & 5.56 & 1.15 & 4.98 & 0.75 & 3.79 & 0.8 & 2.16 & 0.34 & 2.06 & 0.3 & 142 & 15.2 & 157 \\
\hline 45 & 3.05 & 33.7 & 65.7 & 7.47 & 28.1 & 5.53 & 1.12 & 4.97 & 0.73 & 3.88 & 0.83 & 2.23 & 0.35 & 2.18 & 0.32 & 142 & 15.5 & 157 \\
\hline 47 & 3.18 & 34.9 & 68.3 & 7.85 & 29.6 & 5.83 & 1.22 & 5.2 & 0.73 & 3.99 & 0.86 & 2.31 & 0.37 & 2.18 & 0.32 & 148 & 16 & 164 \\
\hline 49 & 3.3 & 35.1 & 68.3 & 7.88 & 29.5 & 5.83 & 1.19 & 5.28 & 0.73 & 3.92 & 0.84 & 2.29 & 0.36 & 2.2 & 0.33 & 148 & 15.9 & 164 \\
\hline 51 & 3.42 & 34.4 & 67.6 & 7.75 & 29.1 & 5.75 & 1.16 & 5.11 & 0.74 & 3.85 & 0.82 & 2.22 & 0.35 & 2.12 & 0.32 & 146 & 15.5 & 161 \\
\hline 53 & 3.54 & 35.1 & 68.6 & 7.88 & 29.4 & 5.82 & 1.17 & 5.3 & 0.77 & 4.03 & 0.85 & 2.32 & 0.37 & 2.22 & 0.32 & 148 & 16.2 & 164 \\
\hline 55 & 3.66 & 34.6 & 67 & 7.75 & 28.9 & 5.78 & 1.19 & 5.21 & 0.75 & 4.08 & 0.88 & 2.37 & 0.37 & 2.29 & 0.33 & 145 & 16.3 & 162 \\
\hline 57 & 3.78 & 34.4 & 66.8 & 7.69 & 28.8 & 5.7 & 1.15 & 5.11 & 0.71 & 3.8 & 0.81 & 2.23 & 0.34 & 2.15 & 0.32 & 145 & 15.5 & 160 \\
\hline 59 & 3.91 & 34.5 & 67.3 & 7.77 & 29.3 & 5.75 & 1.16 & 5.14 & 0.75 & 3.88 & 0.83 & 2.22 & 0.35 & 2.18 & 0.32 & 146 & 15.7 & 161 \\
\hline 61 & 4.03 & 34.1 & 65.8 & 7.55 & 28.2 & 5.57 & 1.15 & 5.04 & 0.74 & 3.83 & 0.8 & 2.19 & 0.34 & 2.09 & 0.32 & 142 & 15.3 & 158 \\
\hline 63 & 4.15 & 34.4 & 66.8 & 7.71 & 28.9 & 5.69 & 1.17 & 5.19 & 0.76 & 3.96 & 0.85 & 2.27 & 0.36 & 2.2 & 0.33 & 145 & 15.9 & 161 \\
\hline 65 & 4.27 & 34.6 & 67.5 & 7.79 & 29.2 & 5.64 & 1.17 & 5.16 & 0.77 & 3.86 & 0.8 & 2.17 & 0.34 & 2.1 & 0.31 & 146 & 15.5 & 162 \\
\hline 67 & 4.39 & 36.2 & 70.1 & 8.04 & 30.1 & 5.82 & 1.21 & 5.27 & 0.78 & 3.95 & 0.83 & 2.24 & 0.34 & 2.17 & 0.33 & 151 & 15.9 & 167 \\
\hline 69 & 4.52 & 35.6 & 69 & 7.9 & 29.4 & 5.72 & 1.2 & 5.23 & 0.76 & 3.92 & 0.82 & 2.2 & 0.34 & 2.09 & 0.32 & 149 & 15.7 & 165 \\
\hline 71 & 4.64 & 35.2 & 68.3 & 7.87 & 29.6 & 5.8 & 1.18 & 5.22 & 0.75 & 3.85 & 0.81 & 2.21 & 0.35 & 2.13 & 0.32 & 148 & 15.7 & 164 \\
\hline 73 & 4.76 & 35.8 & 69.2 & 7.92 & 29.7 & 5.81 & 1.2 & 5.33 & 0.77 & 4.05 & 0.85 & 2.34 & 0.36 & 2.19 & 0.33 & 150 & 16.2 & 166 \\
\hline 75 & 4.88 & 35.4 & 68.7 & 7.87 & 29.5 & 5.79 & 1.17 & 5.26 & 0.79 & 4 & 0.84 & 2.28 & 0.35 & 2.24 & 0.33 & 148 & 16.1 & 165 \\
\hline 77 & 5 & 36.5 & 70.3 & 8.1 & 30.3 & 5.92 & 1.22 & 5.36 & 0.79 & 4.05 & 0.86 & 2.33 & 0.36 & 2.25 & 0.34 & 152 & 16.3 & 169 \\
\hline 79 & 5.13 & 36.4 & 70.9 & 8.1 & 30.5 & 5.97 & 1.22 & 5.4 & 0.82 & 4.14 & 0.87 & 2.33 & 0.37 & 2.26 & 0.34 & 153 & 16.5 & 170 \\
\hline 81 & 5.25 & 35 & 67.8 & 7.78 & 29.2 & 5.69 & 1.17 & 5.18 & 0.78 & 3.89 & 0.82 & 2.22 & 0.34 & 2.12 & 0.32 & 147 & 15.7 & 162 \\
\hline Average & & 34.6 & 67.3 & 7.73 & 29.1 & 5.69 & 1.18 & 5.16 & 0.75 & 3.93 & 0.84 & 2.26 & 0.35 & 2.16 & 0.32 & 146 & 15.8 & 161 \\
\hline C.V. & & 0.04 & 0.04 & 0.03 & 0.03 & 0.03 & 0.03 & 0.03 & 0.04 & 0.04 & 0.04 & 0.04 & 0.04 & 0.04 & 0.04 & 0.03 & 0.04 & 0.03 \\
\hline CJS & & 36.1 & 65.1 & 8.33 & 32.6 & 6.09 & 1.3 & 5.58 & 0.85 & 4.71 & 0.98 & 2.56 & 0.37 & 2.23 & 0.33 & 150 & 17.6 & 167 \\
\hline HHS & & 29 & 53.9 & 7.07 & 26.7 & 4.99 & 1.04 & 4.65 & 0.75 & 3.92 & 0.84 & 2.23 & 0.35 & 2.05 & 0.31 & 123 & 15.1 & 138 \\
\hline UCCEC & & 33 & 64 & 7.3 & 28 & 5 & 1.12 & 4.4 & 0.67 & 4 & 0.8 & 2.3 & 0.34 & 2.2 & 0.33 & 138 & 15 & 153 \\
\hline
\end{tabular}

C.V. coefficient of variance; CJS. Yangtze River sediment; HHS. Yellow River Sediment; UCCES. upper continental crust of east China. The REE data of CJS and HHS from the paper of Yang and Li (1999a); the major elements data from the paper of Yang and Li (1999b); the trace elements data from the paper of Yang et al. (2003); the elements data of UCCEC from the paper of Yan et al. (1997). 
Yellow River and being dispersed by coastal currents. They have only a small contribution by the Yangtze River (Lee and Chough, 1989). The coefficient of variance (CV) of the elements is very small (Table 4), which indicates that the provenance has been relatively stable and suggests a continuous single source input. The distribution of most elements in core D7 agrees with that of Yangtze River and Yellow River sediments as well as the UCCEC except for $\mathrm{CaO}, \mathrm{P}_{2} \mathrm{O}_{5}, \mathrm{Ba}, \mathrm{Sr}$, and $\mathrm{Li}$ (Figs. 2, 3, 4). The lower contents of $\mathrm{CaO}, \mathrm{P}_{2} \mathrm{O}_{5}, \mathrm{Ba}$ and $\mathrm{Sr}$ might be due to biologic activity in marine environment.

REEs are excellent to trace the sediment origin due to their coherent behavior during weathering, erosion and fluvial transportation as well as their high resistance to chemical mobilization (Vital et al., 1999; Klaver and van Weering, 1993; McLennan, 1992; McLennan and Taylor, 1980). The UCCEC-normalized REE patterns at each layer are similar (Fig. 5), which indicates that the sediment is mainly from the same origin throughout the core. The values of UCCEC-normalized REE are near to 1, and between those of CJS and HHS, which also suggests that the sediments of Core D7 are mainly from the continental crust of East China. The concentration of REE in the sediment is similar to the provenance which strongly suggests that post-depositional processes, such as re-working and diagenesis, are not significant (Abanda and Hannigan, 2006). So, the vertical distribution of elements may be used to reconstruct climate and environment of the sediment provenance.

\subsection{Elemental Ratios}

In Core D7 sediment, the CIA (53.7 to 59.7) suggests low chemical weathering and is consistent with a relatively cool and arid climate in northern China from the Middle Holocene (e.g.,
Kong et al., 2014; Wang et al., 2005; Xiao et al., 2002; Jin and Liu, 2002; Shi et al., 1993). However, the short intervals with lower CIA values indicate that still cooler and more arid events occurred during this epoch, which has also been reported elsewhere (e.g., Liu and Feng, 2012; Sicre et al., 2008).

The ratios of $\mathrm{Al} / \mathrm{Ca}, \mathrm{K} / \mathrm{Ca}, \mathrm{Al} / \mathrm{Na}, \mathrm{K} / \mathrm{Na}, \mathrm{Rb} / \mathrm{Sr}, \mathrm{Li} / \mathrm{Ba}$ and CIA show similar distribution patterns (summarized as periods I to III) albeit with different amplitudes. Obviously, almost all the ratios derived from Core D7 are higher than those of UCCEC except for $\mathrm{Al} / \mathrm{Ca}$ and $\mathrm{K} / \mathrm{Ca}$ at the top of the core (Fig. 6). This indicates that the chemical weathering influenced the elements differently. The highest value of all the ratios at 5.13 cal. ka BP suggests that the chemical weathering was the strongest in this period. However, the lowest ratio value is not always at the same age. For $\mathrm{Al} / \mathrm{Na}, \mathrm{K} / \mathrm{Na}, \mathrm{Li} / \mathrm{Ba}$ and $\mathrm{CIA}$, the lowest value is at $2.93 \mathrm{cal}$. $\mathrm{ka} \mathrm{BP}$, while for $\mathrm{Al} / \mathrm{Ca}, \mathrm{K} / \mathrm{Ca}$ and $\mathrm{Rb} / \mathrm{Sr}$ ratio it is at the top of the core at 0.37 cal. ka BP. The differences may reflect different chemical activities of $\mathrm{Ca}$ and $\mathrm{Na}$. Moreover, the mobility of $\mathrm{Ca}$ is higher than that of $\mathrm{Na}$, so that the lowest values of $\mathrm{Al} / \mathrm{Ca}$ and $\mathrm{K} / \mathrm{Ca}$ at the top of the core, which are even lower than those of the UCCEC (Fig. 6), might be due to another source of $\mathrm{Ca}$, such as autogenic carbonate input. The lowest $\mathrm{Rb} / \mathrm{Sr}$ ratio, occurring at the top of the core, may indicate that $\mathrm{Sr}$ occurs concomitant with carbonate, but the effect is not as strong as on $\mathrm{Al} / \mathrm{Ca}$ and $\mathrm{K} / \mathrm{Ca}$. Furthermore, almost all the element ratios correlate with each other with correlation coefficients $>0.69$, which suggests a common process influencing them. Considering that these are the CIA, $\mathrm{Al} / \mathrm{Na}$, $\mathrm{K} / \mathrm{Na}$ and $\mathrm{Rb} / \mathrm{Sr}$ ratios, this process is most likely the chemical weathering intensity of the East China (Table 5). Obviously, the CIA has the predominant correlation with the element ratios

Table 2 Total variance explained of factor analysis on elements in Core D7 in South Yellow Sea

\begin{tabular}{|c|c|c|c|c|c|c|c|c|c|}
\hline \multirow[t]{2}{*}{ Component } & \multicolumn{3}{|c|}{ Initial eigen values } & \multicolumn{3}{|c|}{ Extraction sums of squared loadings } & \multicolumn{3}{|c|}{ Rotation sums of squared loadings } \\
\hline & Total & $\begin{array}{c}\% \text { of } \\
\text { variance }\end{array}$ & $\begin{array}{c}\text { Cumulative } \\
(\%)\end{array}$ & Total & $\begin{array}{c}\% \text { of } \\
\text { variance }\end{array}$ & $\begin{array}{c}\text { Cumulative } \\
(\%)\end{array}$ & Total & $\begin{array}{c}\% \text { of } \\
\text { variance }\end{array}$ & $\begin{array}{c}\text { Cumulative } \\
(\%)\end{array}$ \\
\hline 1 & 9.890 & 61.811 & 61.811 & 9.890 & 61.811 & 61.811 & 6.263 & 39.145 & 39.145 \\
\hline 2 & 2.558 & 15.987 & 77.798 & 2.558 & 15.987 & 77.798 & 4.388 & 27.428 & 66.573 \\
\hline 3 & 1.295 & 8.092 & 85.889 & 1.295 & 8.092 & 85.889 & 3.091 & 19.317 & 85.889 \\
\hline 4 & 0.774 & 4.839 & 90.728 & & & & & & \\
\hline 5 & 0.568 & 3.549 & 94.277 & & & & & & \\
\hline 6 & 0.388 & 2.428 & 96.705 & & & & & & \\
\hline 7 & 0.231 & 1.444 & 98.150 & & & & & & \\
\hline 8 & 0.152 & 0.948 & 99.097 & & & & & & \\
\hline 9 & 0.095 & 0.594 & 99.691 & & & & & & \\
\hline 10 & 0.021 & 0.132 & 99.823 & & & & & & \\
\hline 11 & 0.011 & 0.066 & 99.889 & & & & & & \\
\hline 12 & 0.007 & 0.043 & 99.933 & & & & & & \\
\hline 13 & 0.005 & 0.032 & 99.965 & & & & & & \\
\hline 14 & 0.004 & 0.025 & 99.990 & & & & & & \\
\hline 15 & 0.002 & 0.010 & 100.000 & & & & & & \\
\hline 16 & $2.963 \mathrm{E}-16$ & $1.852 \mathrm{E}-15$ & 100.000 & & & & & & \\
\hline
\end{tabular}

Extraction Method. principal component analysis. 
Table 3 Component matrix of factor analysis on elements in Core D7 in South Yellow Sea

\begin{tabular}{|c|c|c|c|c|c|c|}
\hline \multirow{2}{*}{ Component } & \multicolumn{3}{|c|}{ Component matrix } & \multicolumn{3}{|c|}{ Rotated component matrix } \\
\hline & 1 & 2 & 3 & 1 & 2 & 3 \\
\hline $\mathrm{Li}$ & 0.961 & -0.073 & -0.177 & 0.840 & 0.405 & -0.301 \\
\hline $\mathrm{Rb}$ & 0.974 & 0.040 & -0.122 & 0.822 & 0.495 & -0.214 \\
\hline $\mathrm{Sr}$ & -0.557 & 0.733 & 0.223 & -0.521 & 0.111 & 0.784 \\
\hline $\mathrm{Ba}$ & 0.819 & 0.112 & 0.370 & 0.391 & 0.786 & -0.224 \\
\hline $\mathrm{Al}_{2} \mathrm{O}_{3}$ & 0.973 & 0.022 & -0.178 & 0.856 & 0.446 & -0.216 \\
\hline $\mathrm{CaO}$ & -0.479 & 0.747 & -0.042 & -0.288 & -0.030 & 0.839 \\
\hline $\mathrm{Fe}_{2} \mathrm{O}_{3}$ & 0.948 & 0.027 & -0.279 & 0.903 & 0.361 & -0.179 \\
\hline $\mathrm{K}_{2} \mathrm{O}$ & 0.959 & 0.043 & -0.209 & 0.867 & 0.424 & -0.185 \\
\hline $\mathrm{MgO}$ & 0.949 & 0.090 & -0.242 & 0.884 & 0.411 & -0.131 \\
\hline $\mathrm{MnO}$ & 0.626 & -0.489 & 0.263 & 0.274 & 0.372 & -0.698 \\
\hline $\mathrm{Na}_{2} \mathrm{O}$ & -0.256 & 0.671 & -0.120 & -0.074 & 0.015 & 0.724 \\
\hline $\mathrm{P}_{2} \mathrm{O}_{5}$ & 0.119 & 0.588 & -0.544 & 0.480 & -0.104 & 0.644 \\
\hline $\mathrm{TiO}_{2}$ & 0.906 & 0.107 & -0.070 & 0.741 & 0.517 & -0.145 \\
\hline LREE & 0.772 & 0.330 & 0.459 & 0.311 & 0.904 & -0.031 \\
\hline HREE & 0.796 & 0.401 & 0.237 & 0.477 & 0.785 & 0.083 \\
\hline$\sum \mathrm{REE}$ & 0.786 & 0.342 & 0.443 & 0.333 & 0.906 & -0.020 \\
\hline
\end{tabular}

Extraction method. principal component analysis; rotation methods: varimax with Kaiser normalization; rotation converged in 6 iterations; 3 components extracted.

Table 4 Average content of elements in core D7, CJS and HHS and UCCEC

\begin{tabular}{|c|c|c|c|c|c|c|c|c|c|c|c|c|c|c|c|c|}
\hline \multirow[t]{2}{*}{ Element } & $\mathrm{Al}_{2} \mathrm{O}_{3}$ & $\mathrm{CaO}$ & $\mathrm{Fe}_{2} \mathrm{O}_{3}$ & $\mathrm{~K}_{2} \mathrm{O}$ & $\mathrm{MgO}$ & $\mathrm{MnO}$ & $\mathrm{Na}_{2} \mathrm{O}$ & $\mathrm{P}_{2} \mathrm{O}_{5}$ & $\mathrm{TiO}_{2}$ & $\mathrm{Rb}$ & $\mathrm{Sr}$ & $\mathrm{Ba}$ & $\mathrm{Li}$ & LREE & HREE & $\sum \mathrm{REE}$ \\
\hline & \multicolumn{9}{|c|}{$(\%)$} & \multicolumn{7}{|c|}{$(\mu \mathrm{g} / \mathrm{g})$} \\
\hline Core & 12.63 & 2.96 & 4.87 & 2.51 & 2.37 & 0.081 & 2.11 & 0.128 & 0.733 & 109 & 138 & 382 & 52.7 & 146 & 15.8 & 161 \\
\hline $\mathrm{CV}$ & 0.06 & 0.13 & 0.09 & 0.06 & 0.07 & 0.11 & 0.03 & 0.05 & 0.03 & 0.08 & 0.06 & 0.03 & 0.14 & 0.03 & 0.04 & 0.03 \\
\hline CJS & 11.64 & 3.06 & 5.49 & 2.2 & 2.91 & 0.107 & 1.47 & 0.18 & 0.982 & 115 & 147 & 473 & 45 & 150 & 17.6 & 167 \\
\hline HHS & 9.86 & 3.88 & 3.35 & 1.95 & 1.84 & 0.056 & 2.25 & 0.131 & 0.523 & 76.9 & 218 & 498 & 21.2 & 123 & 15.1 & 138 \\
\hline UCCEC & 14.75 & 4.78 & 2.07 & 2.95 & 2.31 & 0.078 & 3.14 & 0.137 & 0.512 & 95 & 300 & 640 & 20 & 138 & 15 & 153 \\
\hline
\end{tabular}

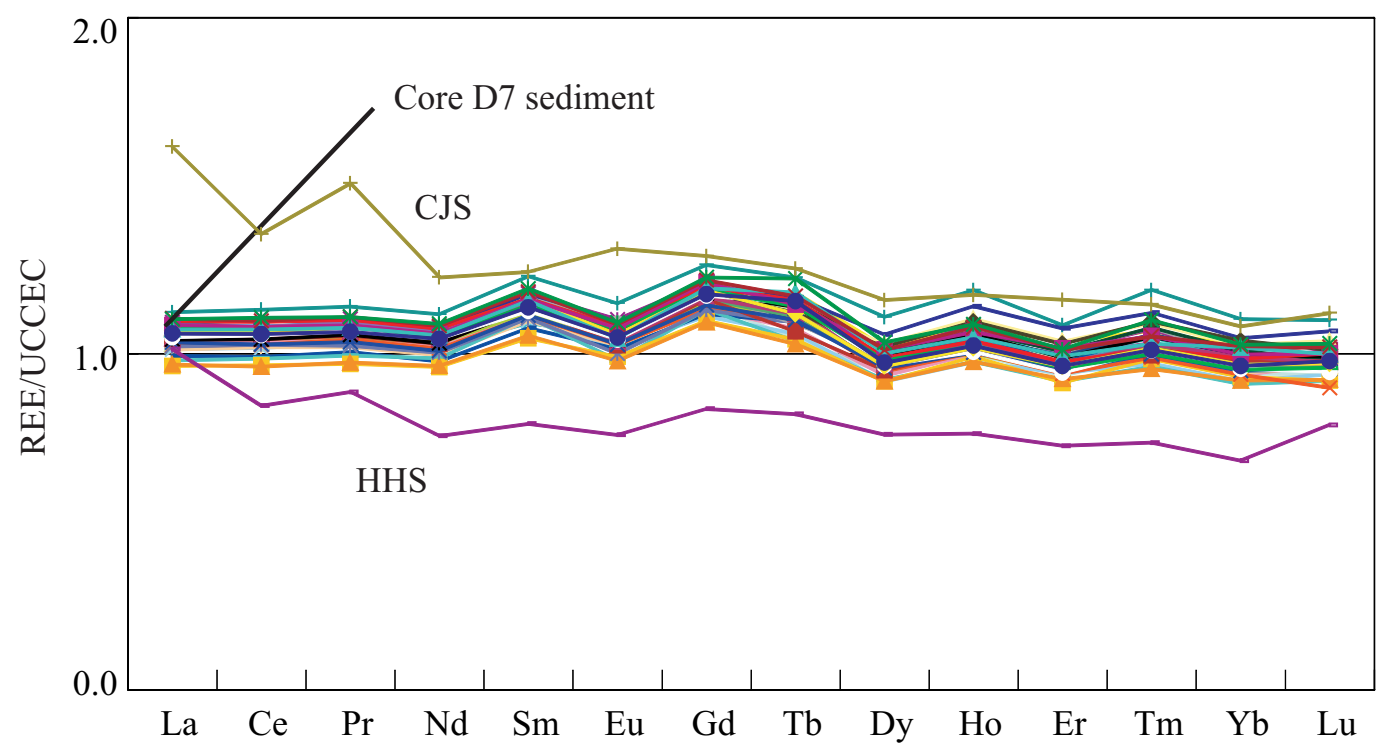

Figure 5. UCCEC normalized REE patterns at each layer of the Core D7 in South Yellow Sea, CJS. Yangtze River sediment; HHS. Yellow River sediment (Yang and Li, 1999a). 


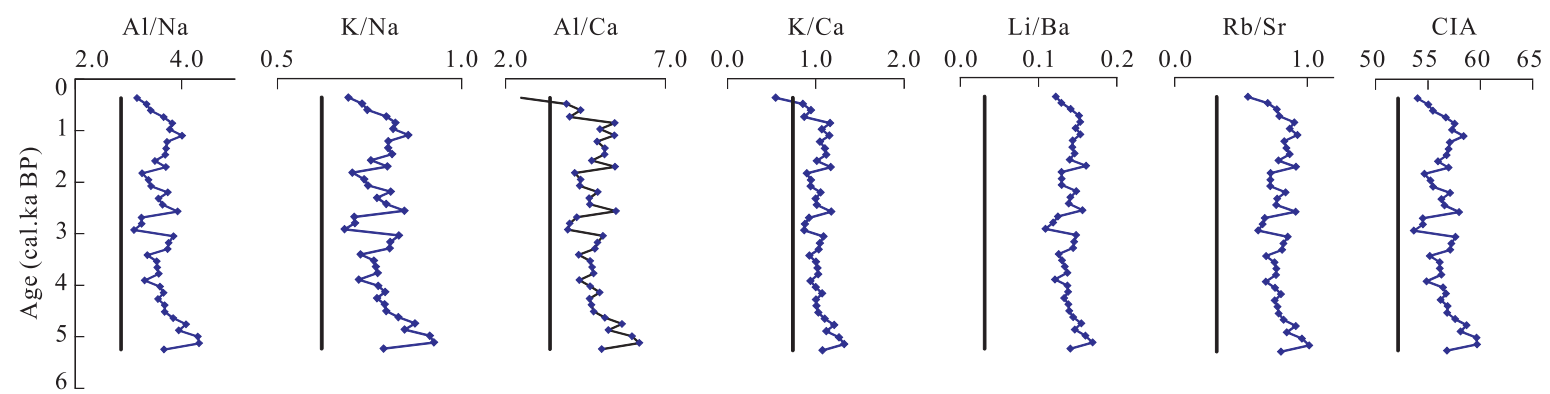

Figure 6. Vertical distributions of elemental ratios and CIA in Core D7 sediment in South Yellow Sea (the black line representing the elemental ratios of upper continental crust of East China).

Table 5 Coefficient of correlation between different element ratios $(n=41, p<0.05)$

\begin{tabular}{lccccccc}
\hline & $\mathrm{Al} / \mathrm{Na}$ & $\mathrm{Al} / \mathrm{Ca}$ & $\mathrm{K} / \mathrm{Na}$ & $\mathrm{K} / \mathrm{Ca}$ & $\mathrm{Rb} / \mathrm{Sr}$ & $\mathrm{Li} / \mathrm{Ba}$ & $\mathrm{CIA}$ \\
\hline $\mathrm{Al} / \mathrm{Na}$ & 1 & 0.888 & 0.996 & 0.998 & 0.938 & 0.791 & 0.997 \\
$\mathrm{Al} / \mathrm{Ca}$ & & 1 & 0.877 & 0.879 & 0.941 & 0.688 & 0.894 \\
$\mathrm{~K} / \mathrm{Na}$ & & & 1 & 0.997 & 0.932 & 0.798 & 0.993 \\
$\mathrm{~K} / \mathrm{Ca}$ & & & & 1 & 0.934 & 0.799 & 0.993 \\
$\mathrm{Rb} / \mathrm{Sr}$ & & & & & 1 & 0.779 & 0.943 \\
$\mathrm{Li} / \mathrm{Ba}$ & & & & & & 1 & 0.796 \\
$\mathrm{CIA}$ & & & & & & & 1 \\
\hline
\end{tabular}

except $\mathrm{Li} / \mathrm{Ba}$, which indicates that for our core the CIA is the most representative and robust proxy to trace the chemical weathering intensity.

\subsection{Paleoclimate Implication}

The reconstructed temperature is in the range of modern mean annual temperature $\left(6-13^{\circ} \mathrm{C}\right)$ for the interval $1951-1990$ in the catchment of the Yellow River (Hao and Guo, 2005). The reconstructed MAP is higher than the current values in the upper and middle river areas $\left(150-500 \mathrm{~mm} \cdot \mathrm{yr}^{-1}\right)$, and comparable to those in the lower (550-650) part of the catchment, especially the Shandong Peninsula (Hao and Guo, 2005; Fig. 7). The results suggest that the CIA reflects the climate change in the Yellow River catchment. The reconstructed MAT and MAP seem to reflect the climate in different areas. This might be due to the weak correlation between MAT and the K/Al and Na/Al ratios (Sheldon et al., 2002). In any case, the calculated MAT and MAP can still be used as proxies for climate change in the sediment source areas.

The synchronous changes of the MAT and MAP records (Fig. 7) suggest that the relatively higher precipitation is associated with higher temperatures in the source region. This is typical for the Asian monsoon system with warm-wet and cool-dry seasons alternating. This system responds to the Northern Hemisphere summer solar insolation, and as such our results are consistent with stalagmite records from Southwest China and peat records from the Tibetan Plateau (Wang et al., 2005; Hong et al., 2003).

The vertical distribution of the climate parameters deduced from geochemical records in Core D7 shows three intervals though which the variation is relatively low (Fig. 7). In interval I (5.3-2.9 cal. ka BP), both MAT and MAP increased quickly from 5.3 to 5.0 cal. ka BP, and decreased slowly from 5.0 to 2.9 cal. ka BP. The warmest and most humid stage around $5.0 \mathrm{ka}$ may reflect the "Holocene optimum" from 8.5-3.0 cal. ka BP (Selvaraj et al., 2007; Stott et al., 2004; Haug et al., 2001).

In Period II (2.9-0.9 cal. ka BP), the fluctuations of MAP and MAT indicate frequent monsoon change. The coldest and driest climate occurred between 2.9-2.7 cal. ka BP, indicating that the winter monsoon became stronger in this interval. The result is consistent with the $\delta^{18} \mathrm{O}$ records from GISP2 (Fig. 7c) and Okinawa Trough sediments (Fig. 7d) (Chang et al., 2008; Stuiver et al., 1997, 1995). There was a relatively warm and humid episode around $1.1 \mathrm{cal}$. ka BP, which is consistent with the Medieval Warm Period in the Northern Hemisphere (Fig. 7) (Stott et al., 2004; Haug et al., 2001).

In Period III, (0.9-0.3 cal. ka BP), both MAT and MAP decreased gradually, suggesting a trend to colder and drier conditions.

\section{CONCLUSIONS}

After thorough studies on major elements, trace elements and REE in Core D7 from the southern Yellow Sea, we conclude that:

(1) The sediments in Core D7 are mainly from the upper crust of eastern China from which they were carried by the Yellow River and Yangtze River to the location of D7, with the Yellow River input dominating.

(2) The strong covariance of the element ratios, including $\mathrm{Al} / \mathrm{Ca}, \mathrm{K} / \mathrm{Ca}, \mathrm{Al} / \mathrm{Na}, \mathrm{K} / \mathrm{Na}, \mathrm{Rb} / \mathrm{Sr}, \mathrm{Li} / \mathrm{Ba}$ and $\mathrm{CIA}$, throughout the core suggests that they are modified by the same process, which we identify as chemical weathering in the sediment source region.

(3) In our study, the CIA appears to be the most robust proxy for tracing climate change. It indicates a cool and arid climate in North China for the investigated interval. The reconstructed MAP and MAT derived from the CIA index indicate that temperature and precipitation increase and decrease synchronously, driven by the relative intensities of the summer and winter monsoons. The reconstructed precipitation and temperature show three intervals: I, 5.3-2.9 cal. ka BP, II, 2.9- 0.9 cal. ka BP and III, 0.9-0.3 cal. ka BP which can be related to major climatic periods described for North China and elsewhere since the Middle Holocene.

The element ratios in alluvial fan sediments appear to be powerful tools to evaluate the climate and environment change in the catchment area. 

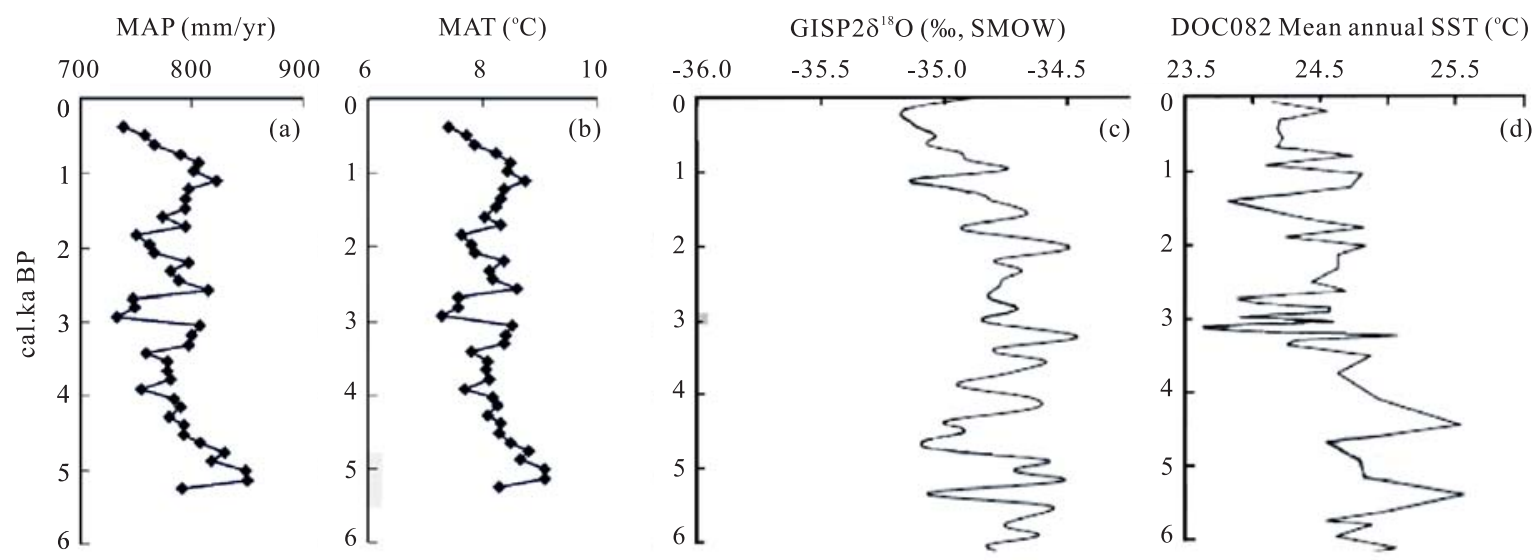

Figure 7. Comparison of mean annual precipitation (MAP) (a) and mean annual temperature (MAT) (b) from geochemical climofunctions with the $\delta^{18} \mathrm{O}$ distribution in GISP2 (c) (Stuiver et al., 1997, 1995) and the mean annual SST from Okinawa Trough sediment (d) (Chang et al., 2008).

\section{ACKNOWLEDGMENTS}

This work was funded by the "Strategic Priority Research Program" of the Chinese Academy of Sciences (Nos. XDA11020102 and XDA05030402), and the National Natural Science Foundation of China (41376090), Research Fund for the Doctoral Program of Higher Education of China (No. 20120145120017), Marine Safeguard Project (No. GZH201200503) and the Special Fund for Basic Scientific Research of Central Colleges, China University of Geosciences, Wuhan. We thank Dr. Xuebo Yin from Institute of Oceanology, Chinese Academy of Sciences for analyses of the major, trace and REE concentration.

\section{REFERENCES CITED}

Abanda, P. A., Hannigan, R. E., 2006. Effect of Diagenesis on Trace Element Partitioning in Shales. Chemical Geology, 230 (1-2): 42-59

Alexander, C. X., DeMaster, D. J., Nittrouer, C. A., 1991. Sediment Accumulation in a Modern Epicontinental-Shelf Setting in the Yellow Sea. Marine Geology, 98: 51-72

Chang, F., Li, T., Zhuang, L., et al., 2008. A Holocene Paleotemperature Record Based on Radiolaria from the Northern Okinawa Trough (East China Sea). Quaternary International, 183: 115-122

Chen, F., Li, J., Zhang, W., 1991. Lanzhou Loess Profile and Its Comparison with Deep Sea Sediment and Antarctic Ice Core. Geological Journal, 24(2): 201-209

Chen, J., An, Z. S., Head, J., 1999. Variation of Rb/Sr Ratios in the Loess-Paleosol Sequences of Central China during the Last 130000 Years and Their Implications for Monsoon Paleoclimatology. Quaternary Research, 51: 215-219

Cheng, Z., Shi, X., Liu, D., et al., 2001. The Assemblage Characteristics of Micropaleontology in Core B10 Sediment and the Environment Evolvement in South Yellow Sea. Chinese Science Bulletin, 46: 45-51

Chough, S. K., Kim, D. C., 1981. Dispersal of Fine-Grained Sediments in the Southeastern Yellow Sea: A Steady-State Model. Journal of Sedimentary Petrology, 51: 721-728

Cole, J. M., Goldstein, S. L., de Menocal, P. B., et al., 2009.
Contrasting Compositions of Saharan Dust in the Eastern Atlantic Ocean during the Last Deglaciation and African Humid Period. Earth and Planetary Science Letters, 278: 257-266

Colin, C., Turpin, L., Blamart, D., et al., 2006. Evolution of Weathering Patterns in the Indo-Burman Ranges over tha Last 280 Kyr: Effects of Sediment Provenance on ${ }^{87} \mathrm{Sr} /{ }^{86} \mathrm{Sr}$ Ratios Tracer. Geochemistry Geophysics Geosystems, 7: Q03007. doi:10.1029/2005GC000962

Dahl, S. O., Nesje, A., 1996. A New Approach to Calculating Holocene Winter Precipitation by Combining Glacier Equilibrium-Line Altitudes and Pine-Tree Limits: A Case Study from Hardangerjokulen, Central Southern Norway. Holocene, 6: 381-398

Dansgarrd, W., Johnsen, S. J., Clausen, H. B., et al., 1993. Evidence for General Instability of Past Climate from a 250-Kyr Ice-Core Record. Nature, 364: 218-220

Das, A., Krishnaswami, S., 2007. Elemental Geochemistry of River Sediments from the Deccan Traps, India: Implications to Sources of Elements and Their Mobility during Basalt-Water Interaction. Chemical Geology, 242: 232-254

Dasch, E. J., 1969. Strontium Isotopes in Weathering Profiles, Deep-Sea Sediments, and Sedimentary Rocks. Geochimica et Cosmochimica Acta, 33: 1521-1552

DeMaster, D. J., Mckee, B. A., Nittrourer, C. A., et al., 1985. Rates of Sediment Accumulation and Particle Reworking Based on Radiochemical Measurement from Continental Shelf Deposit in the East China Sea. Continental Shelf Research, 4: 143-158

Eisenhauer, A., Meyer, H., Rachold, V., et al., 1999. Grain Size Separation and Sediment Mixing in Arctic Ocean Sediments: Evidence from the Strontium Isotope Systematic. Chemical Geology, 158: 173-188

Fedo, C. M., Nesbitt, H. W., Young, G. M., 1995. Unravelling the Effects of Potassium Metasomatism in Sedimentary Rocks and Paleosols, with Implications for Paleoweathering Conditions and Provenance. Geology, 23: 921-924

Gao, S., Cheng, P., Wang, Y. P., et al., 2000. Characteristics of 
Suspended Sediment Concentrations over the Areas Adjacent to Changjiang River Estuary, the Summer of 1998. Marine Science Bulletin, 2: 14-23

Gasse, F., Arnold, M., Fontes, J. C., et al., 1991. A 13 000-Year Climate Record from Western Tibet. Nature, 353: $742-745$

Ge, Y., Shi, X., Zhu, R., et al., 2005. The Magnetic Stratum and Its Environmental Significance of Core EY02-2 in South Yellow Sea. Chinese Science Bulletin, 50: 2531-2540 (in Chinese)

Goldberg, K., Humayun, M. 2010. The Applicability of the Chemical Index of Alteration as a Paleoclimatic Indicator: An Example from the Permian of the Paraná Basin, Brazil. Palaeogeography, Palaeoclimatology, Palaeoecology, 293: $175-183$

Goldstein, S. L., 1988. Decoupled Evolution of Nd and Sr Isotopes in the Continental Crust and the Mantle. Nature, 336: 733-738

Grootes, P. M., Stuiver, M., 1997. Oxygen 18/16 Variability in Greenland Snow and Ice with $10^{3}$-to $10^{5}$-Year Time Resolution. Journal of Geophysical Research, C102: 26455-26470

Hao, Q., Guo, Z., 2005. Spatial Variations of Magnetic Susceptibility of Chinese Loess for the Last 600 Kyr: Implications for Monsoon Evolution. Journal of Geophysical Research, 110: B12101. doi: 10.1029/2005JB003765, 2005

Harrison, S. P., Digerfeldt, G., 1993. European Lakes as Palaeohydrological and Palaeoclimatic Indicators. Quaternary Science Reviews, 12: 233-248

Haug, G. H., Hughen, K. A., Sigman, D. M., et al., 2001. Southward Migration of the Intertropical Convergence Zone through the Holocene. Science, 293: 1304-1308

Hemming, S. R., 2007. Terrigenous Sediments. In: Elias S.A. ed. Encyclopedia of Quaternary Science, Vol. 3. Elsevier, Oxford. 1776-1785

Hong, Y., Hong, B., Lin, Q., et al., 2003. Correlation between Indian Ocean Summer Monsoon and North Atlantic Climate during the Holocene. Earth and Planetary Science Letters, 211(3-4) : 371-380

Ingram, B. L., Sloan, D., 1992. Strontium Isotopic Composition of Estuarine Sediments as Paleosalinity Paleoclimate Indicator. Science, 255: 68-72

Jia, Y., Huang, C., Pang, J., et al., 2005. Variations of Li/Ba Ratios and Its Paleoclimatic Significance in the Holocence Soil Profile. Quaternary Sciences, 25(6) : 77-83 (in Chinese with English abstract)

Jin, G., Liu, D., 2002. Mid-Holocene Climate Change in North China, and the Effect on Cultural Development. Chinese Science Bulletin, 47: 408-413

Kim, J. M., Kennett, J. P. 1998. Paleoenvironmental Changes Associated with the Holocene Marine Transgression, Yellow Sea (Hwanghae). Marine Micropaleontology, 34: 71-89

Klaver, G. T., van Weering, T. C. E., 1993. Rare Earth Element Fractionation by Selective Sediment Dispersal in Surface Sediments: The Skagerrak. Marine Geology, 111: 345-359

Kong, D., Zong, Y., Jia, G., et al., 2014. The Development of
Late Holocene Coastal Cooling in the Northern South China Sea. Quaternary International, 349: 300-307

Lee, H. J., Chough, S. K. 1989. Sediment Distribution, Dispersal and Budget in the Yellow Sea. Marine Geology, 87(2-4) : 195-205

Liu, F., Feng, Z. 2012. A Dramatic Climatic Transition at $\sim 4000$ cal. Yr BP and Its Cultural Responses in Chinese Cultural Domains. The Holocence, 22: 1181-1197

Liu, J., Saito, Y., Kong, X., et al., 2009. Geochemical Characteristics of Sediment as Indicators of Post-Glacial Environmental Changes Off the Shandong Peninsula in the Yellow Sea. Continental Shelf Research, 29: 846-855

Lü, X., Pang, B., Song, J., et al., 2014. Chronology of Core D7 Sediment in the West Continental Shelf of the South Yellow Sea. Marine Environmental Sciences, 33: 550-555

Maynard, J. B. 1992. Chemistry of Modern Soils as a Guide to Interpreting Precambrian Paleosols. The Journal of Geology, 100: 279-289

McLennan, S. M., 1989. Rare Earth Elements in Sedimentary Rocks: Influence of Provenance and Sedimentary Processes. In: Lipin, B. R., McKay, G.A., eds., Geochemistry and Mineralogy of Rare Earth Elements: Rev. Mineral, 21: 169-200

McLennan, S. M., 1992. Rare Earth Elements in Sedimentary Rocks: Influence of Provenance and Sedimentary Processes. In: Lipin, B. R., McKay, G. A., eds., Geochemistry and Mineralogy of Rare Earth Elements, Reviews in Mineralogy 21. Mineralogical Society of America, Washington, DC

McLennan, S. M., 1993. Weathering and Global Denudation. The Journal of Geology, 101: 295-303

McLennan, S. M., Taylor, S. R., 1980. Rare Earth Elements in Sedimentary Rocks, Granites and Uranium Deposits of the Pine Creek Geosyncline. In: Ferguson, J., Coleby, A. B., eds., Uranium in the Pine Creek Geosyncline IAEA. Vienna, 175-190

McLennan, S. M., Taylor, S. R., McCulloch, M. T., et al., 1990. Geochemical and $\mathrm{Nd}, \mathrm{Sr}$ Isotopic Composition of Deep-Sea Turbidities: Crustal Evolution and Plate Tectonic Associations. Geochimica et Cosmochimica Acta, 54(7): 2015-2050

Milliman, J. D., Beardsley, R. C., Yang, Z. S., et al., 1985a. Modern Yellow River-Derived Muds on the Outer Shelf of the East China Sea: Identification and Potential Transport Mechanisms. Continental Shelf Research, 4: 175-188

Milliman, J. D., Shen, H. T., Yang, Z. S., et al., 1985b. Transport and Deposition of River Sediment in the Changjiang Estuary and Adjacent Continental Shelf. Continental Shelf Research, 4: 37-45

Morrill, C., Overpeck, J. T., Cole, J. E., et al., 2006. Holocene Variations in the Asian Monsoon Inferred from the Geochemistry of Lake Sediments in Central Tibet. Quaternary Research, 65: 232-243

Mou, B., 1999. Elemental Geochemistry. Science Press, Beijing, 149-152, 177-180 (in Chinese)

Nesbitt, H. W., Markovics, G., 1997. Weathering of Granodioritic Crust, Long-Term Storage of Elements in Weathering Profiles, and Petrogenesis of Siliciclastic Sediments. 
Geochimica et Cosmochimica Acta, 61(8): 1653-1670

Nesbitt, H. W., Markovics, G., Price, R. C., 1980. Chemical Processes Affecting Alkalis and Alkaline Earths during Continental Weathering. Geochimica et Cosmochimica Acta, 44: 1659-1666

Nesbitt, H. W., Young, G. M., 1996. Effect of Chemical Weathering and Sorting on the Petrogenesis of Siliciclastic Sediments, with Implications for Provenance Studies. The Journal of Geology, 104: 525-542

Nesbitt, H.W., Young, G. M., 1982. Early Proterozoic Climate and Plate Motions Inferred from Major Element Chemistry of Lutite. Nature, 299: 715-717

Park, S. C., Lee, H. H., Han, H. S., et al., 2000. Evolution of Late Quaternary Mud Deposits and Recent Sediment Budget in the Southeastern Yellow Sea. Marine Geology, 170: $271-288$

Porter, S. C., An, Z., 1995. Correlation between Climate Events in the North Atlantic and China during the last Glaciation. Nature, 375: 305-308

Qin, Y. S., Zhao, Y. Y., Chen, L. R., et al., 1989. Geology of the Yellow Sea. China Ocean Press, Beijing (in Chinese)

Ren, M. E., Shi, Y. L., 1986. Sediment Discharge of the Yellow River (China) and Its Effect on the Sedimentation of the Bohai and the Yellow Sea. Continental Shelf Research, 6: $785-810$

Retallack, G. J., 2009. Greenhouse Crises of the Past 300 Million Years. Geological Society of America Bulletin, 121: 1441-1455

Roy, P. D., Caballero, M., Lozano, R., et al., 2008. Geochemistry of Late Quaternary Sediments from Tecocomulco Lake, Central Mexico: Implication to Chemical Weathering and Provenance. Chemie der Erde, 68: 383-393

Schulz, H. D., Vonrab, U., Erlenkeuser, H., 1998. Correlation between Arabian Sea and Greenland Climate Oscillation of the Past 110000 years. Nature, 3931: 54-57

Selvaraj, K., Chen, C. T. A., Lou, J-Y., 2007. Holocene East Asian Monsoon Variability: Links to Solar and Tropical Pacific Forcing. Geophysical Research Letters, 34: L01703. doi: 10.1029/2006GL028155.

Sheldon, N. D., Retallack, G. J., Tanaka, S., 2002. Geochemical Climofunctions from North American Soils and Application to Paleosols across the Eocene-Oligocene Boundary in Oregon. Journal of Geology, 110: 687-696

Shi, Y., Kong, Z., Wang, S., et al., 1992. The Climatic Fluctuation and Significate Affairs in Megathermal Episode in China. Science in China (Ser. B), 22(12): 1300-1308

Shi, Y., Kong, Z., Wang, S., et al., 1993. Mid-Holocene Climates and Environments in China. Global and Planetary Change, 7: 219-233

Shi, Y., Yao, T., Yang, B., 1999. Decadal Climatic Variations Recorded in Guliya Ice Core and Comparison with the Historical Documentary Data from East China during the Last 2000 Years. Science in China (Series D), 42 (Suppl.): 91-100

Sicre, M. A., Yiou, P., Eiríksson, J., et al., 2008. A 4 500-Year Reconstruction of Sea Surface Temperature Variability at Decadal Time-Scales off North Iceland. Quaternary Science Reviews, 27: 2041-2047
Stoll, H. M., Schrag, D. P. 2000. Coccolith $\mathrm{Sr} / \mathrm{Ca}$ as a New Indicator of Coccolithophorid Calcification and Growth Rate. Geochemistry Geophysics Geosystems, 1: 10-18

Stoll, H. M., Schrag, D. P., 1998. Effects of Quaternary Sea Level Cycles on Strontium in Seawater. Geochimica et Cosmochimica Acta, 62: 1107-1118

Stott, L., Cannariato, K., Thunell, R., et al., 2004. Decline of Surface Temperature and Salinity in the Western Tropical Pacific Ocean in the Holocene Epoch. Nature, 431: 56-59

Stuiver, M., Braziunas, T. F., Grootes, P. M., et al., 1997. Is There Evidence for Solar Forcing of Climate in the GISP2 Oxygen Isotope Record? Quaternary Research, 48: 259-266

Stuiver, M., Grootes, P. M., Braziunas, T. F., 1995. The GISP2 $\delta^{18} \mathrm{O}$ Climate Record of the Past 16500 Years and the Role of the Sun, Ocean and Volcanoes. Quaternary Research, 44: 341-354

Vital, H., Stattegger, K., Garbe-Schonberg, C. D., 1999. Composition and Trace-Element Geochemistry of Detrital Clay and Heavy-Mineral Suites of the Lowermost Amazon River: A Provenance Study. Journal of Sedimentary Research Section, 69: 563-575

Wang, B., Lin, H., 2002. Rainy Season of the Asian-Pacific Summer Monsoon. Journal of Climate, 15: 386-396

Wang, S., Zhang, G., Zhang, J., et al., 2007. Geochemical Studies on $\mathrm{Rb}$ and $\mathrm{Sr}$ in the Mud on the Inner Shelf of the East China Sea and their Palaeoclimatic Significance. Science Technology Review, 25(3) : 22-27 (in Chinese with English Abstract)

Wang, W., Feng, Z., Lee, X., et al., 2004. Holocene Abrupt Climate Shifts Recorded in Gun Nuur Lake Core, Northern Mongolia. Chinese Science Bulletin, 49(5) : 520-526

Wang, Y., Chen, H., Edwards, R. L., et al., 2005. The Holocene Asian Monsoon: Links to Solar Changes and North Atlantic Climate. Science, 308: 854-857

Xiang, R., Yang, Z., Saito, Y., et al., 2008. Paleoenvironmental Changes during the Last 8400 Years in the Southern Yellow Sea: Benthic Foraminiferal and Stable Isotopic Evidence. Marine Micropaleontology, 67: 104-119

Xiao, J., Nakamura, T., Lu, H., et al., 2002. Holocene Climate Changes over the Desert/Loess Transition of North-Central China. Earth and Planetary Science Letters, 197: 11-18

Xiong, S., Ding, Z., Zhu, Y., et al., 2010. A $\sim 6$ Ma Chemical Weathering History, the Grain Size Dependence of Chemical Weathering Intensity, and Its Implications for Provenance Change of the Chinese Loesse Red Clay Deposit. Quaternary Science Reviews, 29: 1911-1922

Yan, M., Chi, Q., Gu, T., et al., 1997. Chemical Compositions of Upper Continental Crust in East China. Science in China (Series D), 27(3) : 193-199

Yang, S. Y., Li, C. X., Yang, D. Y., et al., 2004a. Chemical Weathering of Loess Deposits in the Lower Changjiang Valley, China, and Paleoclimatic Implications. Quaternary International, 117: 27-34

Yang, S. Y., Lim, D. I., Jung, H. S., et al., 2004b. Geochemical Composition and Provenance Discrimination of Coastal Sediments around Cheju is Land in the Southern Yellow 
Sea. Marine Geology, 206: 41-53

Yang, S., Li, C., 1999a. REE Geochemistry and Tracing Application in the Yangtze River and the Yellow River Sediments. Geochimica, 28(4): 374-380 (in Chinese with English Abstract)

Yang, S., Li, C. 1999b. Characteristic Element Compositions of the Yangtze and the Yellow River Sediments and Their Geological Background. Marine Geology Quaternary Geology, 19(2): 19-26 (in Chinese with English Abstract)

Yang, S., Li, C., Jun, H., et al., 2003. Geochemistry of Trace Elements in Chinese and Korean River Sediments. Marine
Geology Quaternary Geology, 23(2): 19-24 (in Chinese with English Abstract)

Yang, S., Youn, J. S., 2007. Geochemical Compositions and Provenance Discrimination of the Central South Yellow Sea Sediments. Marine Geology, 243: 229-241

Yin, J., Zheng, Y., Liu, Y., et al., 2007. Statistic Analysis on the ${ }^{14} \mathrm{C}$ Age of Humic Acid and Humin in Paleosol. Seismology and Geology, 29: 381-389

Youn, J., Kim, T. J. 2011. Geochemical Composition and Provenance of Muddy Shelf Deposits in the East China Sea. Quaternary International, 230: 3-12 